\title{
Erratum to: Urban Dynamics and Simulation Models
}

\author{
Denise Pumain and Romain Reuillon
}

\section{Erratum to:}

\section{Pumain and R. Reuillon, Urban Dynamics and Simulation} Models, Lecture Notes in Morphogenesis, DOI 10.1007/978-3-319-46497-8

The original version of the book was inadvertently published without including an author name "Paul Chapron" in the title page and the list of "Authors and Contributors to the Book" in the book front matter. The book front matter has been updated with these changes.

The updated original online version for this bookfrontmatter can be found at DOI 10.1007/978-3-319-46497-8

D. Pumain $(\square)$

Université Paris I Panthéon-Sorbonne and UMR Géographie-Cités, Paris, France

e-mail: pumain@parisgeo.cnrs.fr

R. Reuillon

CNRS, UMR Géographie-Cités and Institut des Systémes Complexes Paris-Ile-de-France,

Paris, France 